\title{
Occupational exposure to Mount Etna's basaltic dust: Assessment of mutagenic and cytotoxic effects
}

\author{
CATERINA LEDDA $^{1}$, SALVATORE COCUZZA ${ }^{2}$, MONICA SALERNO ${ }^{3}$, PAOLA SENIA ${ }^{1}$, \\ SERENA MATERA ${ }^{1}$, VENERANDO RAPISARDA $^{1}$ and CARLA LORETO ${ }^{4}$
}

\author{
${ }^{1}$ Section of Occupational Medicine, Department of Clinical and Experimental Medicine, University of Catania; \\ ${ }^{2}$ Section of Otolaryngology, Department Medical Sciences, Surgical and Advanced Technologies 'G.F. Ingrassia', \\ University of Catania, Catania; ${ }^{3}$ Section of Legal Medicine, Department of Clinical and Experimental Medicine, \\ University of Foggia, Foggia; ${ }^{4}$ Section of Human Anatomy and Histology, Department of Biomedical \\ and Biotechnology Sciences, University of Catania, Catania, Italy
}

Received December 30, 2016; Accepted February 23, 2017

DOI: $10.3892 / \mathrm{mmr} .2017 .6380$

\begin{abstract}
Basalt and volcanic ash are natural constituents of the ground surrounding volcanic areas such as Mount Etna. The dust may be daily inhaled by the general population as well as by several types of workers, such as construction workers. In this experiment, we analyzed the potential mutagenic and cytotoxic effects of the materials used in construction industry, excavated from Mt. Etna. Ground basalt (A), volcanic ash (B), mixed basalt and cement (C) and cement (D) were studied with Ames test, for mutagenic assessment and with MMT assay for cytotoxic evaluation. The Ames test revealed that cement (sample D), showed a higher and significant mutagenicity than the samples A, B and C. MTT assay showed that samples C and $\mathrm{D}$ had a slightly more negative impact on cell viability than A and B. In conclusion, no particular risks seem to exist for construction industry workers, while the exploitation of cement and cement mixed with basalt seems to be a risk for workers, given the high percentage of silica and iron.
\end{abstract}

\section{Introduction}

Basalt and volcanic ash are natural constituents of the ground surrounding volcanic areas such as Mount Etna. The dust may be daily inhaled by the general population as well as by several types of workers, such as tourist guides, forest guards, road maintenance workers, dump and construction workers.

In some of these occupational areas following the manufacturing process, these materials can be mechanically broken down to small particles, easy to inhale. One of these

Correspondence to: Dr Caterina Ledda, Section of Occupational Medicine, Department of Clinical and Experimental Medicine, University of Catania, Via Santa Sofia 78, I-95123 Catania, Italy E-mail: cledda@unict.it

Key words: occupational risk, workers, lung, chest, mutagenicity, cytotoxicity, ash, inhalation occupational areas is the construction one, where basalt and volcanic ash are often excavated in the early construction working phases. Besides, basalt rock, basalt crushed rock (locally called azolo) and volcanic ash are generally exploited as construction material, usually mixed with cement. Volcanic ash is composed of fragments of pulverized rock, minerals and volcanic glass, produced during volcanic eruptions and measuring no more than $2 \mathrm{~mm}$ in diameter (1).

With the word azolo we refer to a specific type of grey-black, sand-like, sharp, less than $2 \mathrm{~mm}$ in diameter stone dust of Mount Etna's area, which derives from the crushing of basaltic rock due either to weathering factors or man's intervention (2). Cement is a binder, a substance exploited in construction that sticks and hardens and can bind materials together. It is used as a component in the production of mortar in masonry and of concrete, which is a mixture of cement and an aggregate (i.e. azolo) to form a strong construction material.

The grain size of construction materials is of critical importance and is conventionally defined in terms of aerodynamic diameter. Thoracic and respirable fractions of particulate matter (PM) are defined as the fragment of inhaled particles capable of going through the larynx and ciliated airways, respectively, during inhalation (3). The PM less than $10 \mu \mathrm{m}\left(\mathrm{PM}_{10}\right)$ in size has a high penetration rate in the airways $(4,5)$.

Potential toxicity of PM depends on its chemical and/or physical composition in association with the size that classifies it as fine $(<1 \mu \mathrm{m})$ and ultrafine $(<0.01 \mu \mathrm{m})$ and makes it breathable and inhalable, reaching the alveolar region (3).

So far, few studies on the toxicity of volcanic dust exist. Studies of exposure to ash related to volcanic activity among the inhabitants of the Etna area (Sicily, Italy) have revealed an increase in the rate of acute respiratory and cardiovascular diseases (6-8) and accumulation of heavy metals in the airways (9). Censi and co-workers (10) theorized that inhalation of air borne particulate from Mt. Etna eruptions may account for the occurrence of fibrotic lung disease. In this study, we analyzed the potential mutagenic and cytotoxic effects of the materials used in construction industry, derived from Mt. Etna. 


\section{Materials and methods}

Sampling. Ground basalt (A), volcanic ash (B), mixed basalt and cement (C) and cement (D) were sampled from the construction site of a subway line in Catania, Sicily. The samples are representative of the volcanic and volcaniclastic lithologies of the place; to make the sample more representative the actual dust produced by excavation works was collected (C and D). Samples were then taken to the laboratory in polyethylene bags. They were dried in an oven at $40^{\circ} \mathrm{C}$ and preserved in polyethylene containers and underwent characterizations by scanning electron microscope (SEM) (Cambridge Stereoscan 360) equipped with energy dispersive X-ray (EDX) system (Oxford Instruments INCA Energy), as previously described (11).

Afterwards, respirable fractions were isolated. Approximately $5 \mathrm{~g}$ samples was aerosolised with HEPA-filtered compressed air using a Naneum AERO PA100 Powder Aerosolizer Model (Particle Measuring Systems, Boulder, CO, USA). The aerosol was passed through a gravitational separator where large particles and agglomerates sedimented after the aerosol. Particles below a maximum theoretical aerodynamic diameter of $6 \mu \mathrm{m}$ (i.e., within the respirable range) (3), were processed for a specific airflow and particle density in the system, then entered a sampling collection chamber.

Mutagenic assessment: Ames test. In order to assess the mutagenic effect, a leaching procedure was carried out, using deionized water (Merck KGaA, Darmstadt, Germany) as a leaching agent. The solid/liquid ratio was 1:20 according to leaching procedure with a speed of $30 \mathrm{rpm}$ for $18 \mathrm{~h}$. The leachates were then filtered through a $0.45-\mu \mathrm{m}$ filter. The Ames mutagenicity test (kindly provided by B.N. Ames; Berkeley, CA, USA) was performed with a standard plate incorporation assay with the TA98, TA100, and TA1535 Salmonella typhimurium strains with and without metabolic activation (12). In short, a preliminary toxic dose range testing was conducted first to select a proper dose range for the mutagenicity test. TA98, TA100 or TA1535 were grown in nutrient broth (NB) at $37^{\circ} \mathrm{C}$ for $18 \mathrm{~h}$, and then diluted for $10^{6}$ - and $10^{7}$-fold by PBS. Leachates of 5, 50, 100, 200, 250 or $500 \mu \mathrm{l}$ were mixed with diluted bacteria $(100 \mu \mathrm{l})$ and soft agar $(2 \mathrm{ml})$. Furthermore, mixed solutions were put onto plates and incubated for $24 \mathrm{~h}$. Mutagenicity effects of leachates were assessed by comparing the bacterial counts between leachates and blank control (deionized water) samples. The results revealed that $500 \mu \mathrm{l} /$ plate of different leachates can be used for Ames assay. Therefore, five volume levels (100, 200, 300, 400 and $500 \mu \mathrm{l} /$ plate) of leachates were selected in line with a previous report and underwent a mutagenicity test $(13,14)$.

The Ames test was validated by counting the number of revertants by means of negative and positive controls, with the spontaneous revertants being within the normal values for the three strains. Moreover, a 2-fold criterion was used to dissect the mutagenic activity, as shown below (12).

Cytotoxic assessment: 3-(4,5-dimethylthiazol-2-yl)-2,5-diphenyltetrazolium bromide (MTT) assay. Primary lines of normal, non immortalized, human adult lung fibroblasts were detected by means of outgrowth from explant in line with
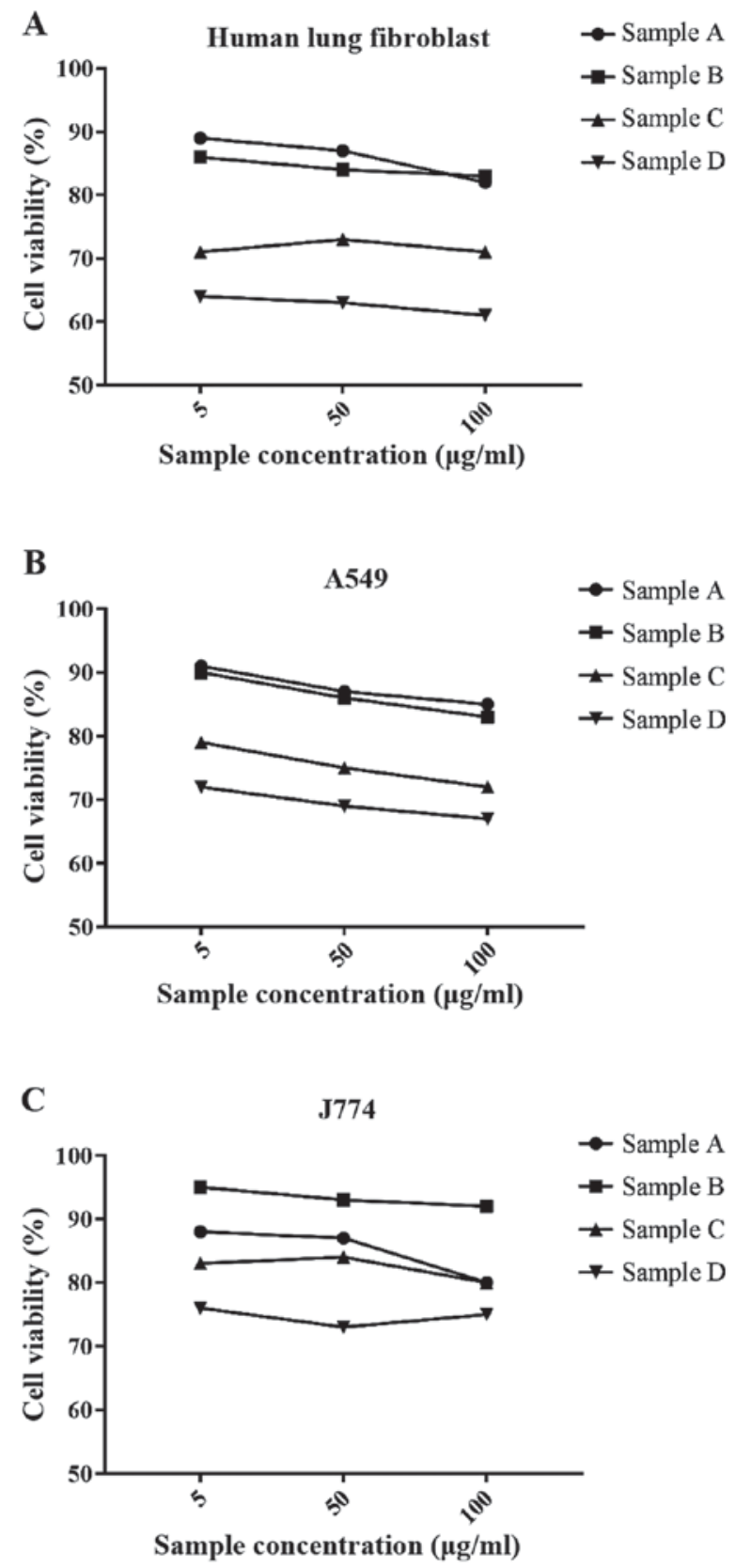

Figure 1. Results of cell viability (\%) in MMT assay: (A) Human lung fibroblast; (B) Epithelial cancer cell A549; (C) Mouse monocyte-macrophage cell $\mathrm{J} 774$

Jordana et al $(15,16)$. Human lung fibroblasts were made to proliferate in $10 \%$ fetal calf serum RPMI, $100 \mathrm{U} / \mathrm{ml}$ penicillin, $100 \mu \mathrm{g} / \mathrm{ml}$ streptomycin, and $25 \mu \mathrm{g} / \mathrm{ml}$ fungizone (Life Technologies, Paisley, UK) and incubated at $37^{\circ} \mathrm{C}$ and $5 \% \mathrm{CO}_{2}$. The medium was substituted every 3 days and subcultures were isolated every 10-12 days. All in all, cell lines were withdrawn just before the tenth passage. A549, which are human bronchoalveolar carcinoma-derived cells with some features peculiar of alveolar epithelial type II cells, were isolated from American Type Culture Collection (ATCC, Rockville, MD, USA) and routinely maintained in Dulbecco's modified Eagle's medium (DMEM) supplemented as before. Cells were trypsinized, counted in a haemocytometer, plated onto 96- or 6-well plates (Costar, Cambridge, MA, USA), and grown in incubator at $37^{\circ} \mathrm{C}$ with $5 \%$ of $\mathrm{CO}_{2}$. 
Table I. Ames test results (mean $\pm \mathrm{SD}$ ).

\begin{tabular}{|c|c|c|c|c|c|c|c|c|}
\hline \multirow[b]{2}{*}{ Strains } & \multicolumn{2}{|c|}{ Sample A } & \multicolumn{2}{|c|}{ Sample B } & \multicolumn{2}{|c|}{ Sample C } & \multicolumn{2}{|c|}{ Sample D } \\
\hline & $-\mathrm{S} 9$ & $+\mathrm{S} 9$ & $-\mathrm{S} 9$ & $+\mathrm{S} 9$ & $-\mathrm{S} 9$ & $+\mathrm{S} 9$ & $-\mathrm{S} 9$ & $+\mathrm{S} 9$ \\
\hline \multicolumn{9}{|l|}{ TA98 } \\
\hline $100 \mu \mathrm{l} /$ plate & $17 \pm 9$ & $14 \pm 10$ & $15 \pm 6$ & $17 \pm 7$ & $27 \pm 9$ & $31 \pm 8$ & $32 \pm 2$ & $41 \pm 3$ \\
\hline $200 \mu \mathrm{l} /$ plate & $15 \pm 8$ & $16 \pm 7$ & $13 \pm 8$ & $16 \pm 6$ & $28 \pm 8$ & $32 \pm 9$ & $31 \pm 3$ & $42 \pm 4$ \\
\hline $300 \mu \mathrm{l} /$ plate & $16 \pm 9$ & $17 \pm 8$ & $17 \pm 4$ & $18 \pm 5$ & $26 \pm 12$ & $31 \pm 9$ & $34 \pm 2$ & $39 \pm 6$ \\
\hline $400 \mu \mathrm{l} /$ plate & $11 \pm 7$ & $13 \pm 8$ & $16 \pm 6$ & $20 \pm 6$ & $24 \pm 7$ & $27 \pm 6$ & $34 \pm 5$ & $43 \pm 4$ \\
\hline Blank & $14 \pm 9$ & $18 \pm 6$ & $15 \pm 6$ & $14 \pm 8$ & $15 \pm 8$ & $16 \pm 5$ & $16 \pm 4$ & $17 \pm 3$ \\
\hline Positive & $154 \pm 30$ & $161 \pm 25$ & $149 \pm 24$ & $168 \pm 26$ & $164 \pm 27$ & $171 \pm 40$ & $159 \pm 23$ & $167 \pm 36$ \\
\hline \multicolumn{9}{|l|}{ TA100 } \\
\hline $100 \mu \mathrm{l} /$ plate & $19 \pm 9$ & $18 \pm 12$ & $24 \pm 9$ & $23 \pm 4$ & $131 \pm 21$ & $134 \pm 24$ & $145 \pm 50$ & $142 \pm 51$ \\
\hline $200 \mu \mathrm{l} /$ plate & $20 \pm 10$ & $21 \pm 7$ & $25 \pm 7$ & $26 \pm 9$ & $135 \pm 20$ & $139 \pm 19$ & $144 \pm 60$ & $145 \pm 48$ \\
\hline $300 \mu \mathrm{l} /$ plate & $24 \pm 8$ & $26 \pm 10$ & $24 \pm 8$ & $30 \pm 11$ & $137 \pm 19$ & $142 \pm 23$ & $146 \pm 49$ & $139 \pm 50$ \\
\hline $400 \mu \mathrm{l} /$ plate & $19 \pm 9$ & $24 \pm 12$ & $27 \pm 13$ & $28 \pm 9$ & $141 \pm 29$ & $145 \pm 32$ & $147 \pm 61$ & $145 \pm 52$ \\
\hline Blank & $106 \pm 36$ & $121 \pm 37$ & $102 \pm 30$ & $116 \pm 38$ & $109 \pm 34$ & $118 \pm 41$ & $117 \pm 66$ & $120 \pm 68$ \\
\hline Positive & $698 \pm 140$ & $1409 \pm 212$ & $653 \pm 127$ & $1398 \pm 197$ & $687 \pm 131$ & $1425 \pm 209$ & $654 \pm 128$ & $1387 \pm 214$ \\
\hline \multicolumn{9}{|l|}{ TA1535 } \\
\hline $100 \mu \mathrm{l} /$ plate & $13 \pm 5$ & $16 \pm 7$ & $16 \pm 8$ & $17 \pm 6$ & $23 \pm 9$ & $25 \pm 10$ & $36 \pm 12$ & $38 \pm 19$ \\
\hline $200 \mu \mathrm{l} /$ plate & $16 \pm 7$ & $19 \pm 11$ & $18 \pm 4$ & $21 \pm 5$ & $24 \pm 11$ & $26 \pm 8$ & $34 \pm 13$ & $40 \pm 13$ \\
\hline $300 \mu 1 /$ plate & $15 \pm 8$ & $16 \pm 12$ & $17 \pm 6$ & $18 \pm 10$ & $23 \pm 7$ & $28 \pm 9$ & $30 \pm 15$ & $32 \pm 16$ \\
\hline $400 \mu 1 /$ plate & $19 \pm 13$ & $17 \pm 9$ & $18 \pm 7$ & $21 \pm 12$ & $26 \pm 12$ & $25 \pm 14$ & $26 \pm 17$ & $29 \pm 16$ \\
\hline Blank & $14 \pm 6$ & $15 \pm 6$ & $12 \pm 4$ & $16 \pm 4$ & $11 \pm 8$ & $13 \pm 7$ & $12 \pm 8$ & $14 \pm 10$ \\
\hline Positive & $649 \pm 78$ & $697 \pm 81$ & $661 \pm 59$ & $689 \pm 76$ & $653 \pm 80$ & $689 \pm 89$ & $668 \pm 75$ & $703 \pm 101$ \\
\hline
\end{tabular}

J774 cells, a murine monocyte-macrophage immortalized cell line, were acquired from ATCC. The cells were grown in $4.5 \mathrm{~g} / 1$ glucose DMEM with $1 \mathrm{mM}$ sodium pyruvate. Samples were suspended in medium and, after sonication, combined with the experimental cultures at concentrations of 5,50 , and $100 \mu \mathrm{g} / \mathrm{ml}\left(1.06,10.6\right.$, and $\left.21.2 \mu \mathrm{g} / \mathrm{cm}^{2}\right)$ for $24 \mathrm{~h}$ before cell collection.

The MTT proliferation assay is based on the conversion by mitochondrial dehydrogenases of the substrate containing a tetrazolium loop into blue, spectrophotometrically quantifiable formazan (17). The level of blue formazan is then used as indirect index of cell density. The optical density of each sample was assessed by a microplate spectrophotometer reader (Multiskan $^{\mathrm{TM}}$ GO Microplate Spectrophotometer, Thermo Scientific, Waltham, MA, USA) at $\lambda 570 \mathrm{~nm}$. Four replicates were carried out for every sample.

Statistical analysis. Ames test results are reported as mean of replicate frequencies and standard deviation (SD). MMT outcomes are shown as percentage of cell viability. Data analysis was performed by GraphPad Prism ver. 7 (GraphPad Software, Inc., La Jolla, CA, USA).

\section{Results}

The Ames test revealed that cement (sample D), showed a higher and more significant mutagenicity than the samples A,
B and C. Table I reports the outcome. The revertants of samples A (ground basalt) and B (volcanic ash) were comparable and below the 2-fold criterion of the control sets, either with or without S9 activation for the strains TA98, TA100 and TA1535. These data showed that sample A and B revealed no mutagenic activity. However, mutagenicity was observed in samples $\mathrm{C}$ (mixed basalt and cement) and $\mathrm{D}$ in a positive, dosedependent manner. The levels of revertants in samples $\mathrm{C}$ and $\mathrm{D}$ increased roughly from 2- to 8-fold by 100, 200, 300, 400 and $500 \mu \mathrm{l} / \mathrm{plate}$ doses of samples in the TA98 and TA100 strain without S9 activation. Furthermore, no dose-response effects of revertants were detected for TA1535, base-pair substitution mutations, in sample C and D (Table I).

MTT assay showed that samples $\mathrm{C}$ and D, at lesser concentration $(5 \mu \mathrm{g} / \mathrm{ml})$ for $24 \mathrm{~h}$, had a slightly negative impact on cell viability. Instead, samples A and B at lower concentration had none. At superior concentrations (50 and $100 \mu \mathrm{g} / \mathrm{ml}$ ) for $24 \mathrm{~h}$ all of the samples (A-D), showed a slightly negative impact on cell ability to metabolize tetrazolium salts (Fig. 1A-C).

\section{Discussion}

Basaltic rocks coming from Mount Etna are an outstanding source of construction materials. These materials have always been exploited without taking into due account the possible risks for the workers' health as well as for the people actually living in these houses $(3,9,11)$. 
Recently, in the South-west area of Mt. Etna a natural asbestiform fibre has been detected, called Fluoro-edenite (FE) (18). FE contaminated lava rocks were used for approximately 50 years to build houses and roads. FE was recognized as carcinogenic to humans and there are several experimental and epidemiological studies showing its toxicity for workers and the population in general (19-31). In this study, we analyzed the potential mutagenic and/or cytotoxic effects of basaltic materials used in the construction field.

To date, there are no studies that have assessed the toxicity of lava stones deriving from Mt. Etna (6-9). We have only data relative to the acute effects on men of volcanic dust and ash after a volcanic eruption. Previously, the potential health consequences undergone by construction workers handling basaltic rock have been investigated in an ecotoxicological study that showed minimal toxicity of the volcanic ash (11).

The results of our study suggested that samples $\mathrm{C}$ (mixed basalt and cement) and $\mathrm{D}$ (cement) might generate derivative metabolites after reactions in the living beings, thereby inducing frame-shift mutations (TA98 and TA1535) and basepair substitution (TA100) (12).

Little is known about the long-term exposure to volcanic ash and their effects on respiratory tract, even less the mainstay of risk assessment in occupational studies. Eruption activity is a natural source of breathable nanoparticles $(1,10)$. The long-term exposure to breathable volcanic ash $(<4 \mu \mathrm{m} \varnothing)$, either because of long-lasting exposure to ash fallout or re-mobilization of ash owing to human activity and wind, has been hypothesized as a potential cause of chronic and/or potentially-fatal lung diseases (silicosis, which occurs through inhaling of crystalline silica), chronic obstructive pulmonary disease, non-specific pneumoconiosis and lung cancer (32).

Our study points out poor mutagenic and cytotoxic effects of ground basalt (A) and volcanic ash (B); whereas cement reveals higher mutagenic and cytotoxic activity, both by itself (D), and in combination with basalt (C). These results are in accordance with an earlier study, conducted with a Vibrio fischeri light inhibition test that highlighted the biotoxicity of the same sample. The results indicated that sample C and D were toxic to V. fischeri (11).

Recently, Cervini-Silva et al (32) demonstrated that degeneration of free radicals by ash particles is due to the presence of iron $\left(\mathrm{Fe}^{3+}\right)$. These observations can account for the high reactivity of samples $C$ and $D$. As a matter of fact, in these samples the content of $\mathrm{Fe}$ is significantly greater than that of $\mathrm{A}$ and $\mathrm{B}$. The results were reported by Ledda et al (11).

Some categories of workers may be exposed to stone dusts both at their workplace and at home. The dust can determine pathological responses in the respiratory tract $(33,34)$. Frequently, illnesses deriving from inhalation of mineral dusts and fibres are usually progressive and cumulative, with 20 to 30 -year latency. Interstitial fibrosis is the most common disease originating from inhaled mineral dusts, that can develop other chronic diseases and, eventually cancer (3).

The study of long-term exposure risks to christobalitebearing ash, after the eruption of Mt. St. Helens and Soufrière Hills, showed several cases of silicosis (35), although the toxicity of volcanic cristobalite had not yet been established (36). In-vitro and in-vivo toxicological tests on volcanic ash produced different results depending on the concentration of silica (Si) $(37,38)$. Yet, no outstanding intra-study differences in reactivity among samples with variable cristobalite contents were detected (39-41).

In our study, the content of $\mathrm{Si}$ is significantly greater in samples $\mathrm{C}$ than in the others (11). Many work categories, particularly those employed in the construction, are exposed to basaltic and volcanic dusts, as well as cement. Furthermore, cement and basalt dusts are often mixed to make mortar. Exposure to cement dust may result in a reduced pulmonary function and chronic respiratory symptoms $(42,43)$. Moreover, in construction workers, there is a significantly higher risk of lung cancer than in the general population (24).

As a conclusion, we can say that no particular risks seem to exist for construction industry workers, while the exploitation of cement and cement mixed with basalt seems to be a risk for workers, given the high percentage of $\mathrm{Si}$ and Fe, especially in the latter sample $\mathrm{C}$. Thus, our findings could contribute to identifying further risk factors adding to the increased rate of lung cancer in this working category (44-46). The results of our study stimulate further tests in order to better clarify the health effects of basaltic dust, especially when used in combination with other substances due to their various manufacturing scopes.

\section{References}

1. Rose WI and Durant AJ: Fine ash content of explosive eruptions. J Volcanol Geotherm Res 186: 32-39, 2009.

2. Venerando R, Amati M, Coloccini S, Bolognini L, Gobbi L and Duscio D: The in vitro release of hydroxyl radicals from dust containing fluoro-edenite fibers identified in the volcanic rocks of Biancavilla (eastern Sicily). Med Lav 94: 200-206, 2003 (In Italian).

3. Brown JS, Gordon T, Price O and Asgharian B: Thoracic and respirable particle definitions for human health risk assessment. Part Fibre Toxicol 10: 12, 2013.

4. Workplace atmospheres-size fraction definitions for measurement of airborne particles (Report No. BS EN 481: 1993) 1993.

5. American Conference of Governmental Industrial Hygienists (ACGIH): TLVs and BEIs: Based on the Documentation of the Threshold Limit Values for Chemical Substances and Physical Agents and Biological Exposure Indices. American Conference of Governmental Industrial Hygienists, Cincinnati, OH, 2005.

6. Lombardo D, Ciancio N, Campisi R, Di Maria A, Bivona L, Poletti V, Mistretta A, Biggeri A and Di Maria G: A retrospective study on acute health effects due to volcanic ash exposure during the eruption of Mount Etna (Sicily) in 2002. Multidiscip Resp Med 8: 51, 2013.

7. Hansell AL, Horwell CJ and Oppenheimer C: The health hazards of volcanoes and geothermal areas. Occup Environ Med 63: 149-156, 125, 2006.

8. Fano V, Cernigliaro A, Scondotto S, Cuccia M, Forastiere F, Nicolosi A, Oliveri C, Scillieri R, Distefano P and Perucci CA: Health effects of environmental contamination due to volcanic ash of Mount Etna in autumn 2002. Epidemiol Prev 29: 180-187, 2005 (In Italian).

9. Censi P, Zuddas P, Randazzo LA, Tamburo E, Speziale S, Cuttitta A, Punturo R, Aricò P and Santagata R: Source and nature of inhaled atmospheric dust from trace element analyses of human bronchial fluids. Environ Sci Technol 45: 6262-6267, 2011.

10. Censi P, Tamburo E, Speziale S, Zuddas P, Randazzo LA, Punturo R, Cuttitta A and Aricò P: Yttrium and lanthanides in human lung fluids, probing the exposure to atmospheric fallout. J Hazard Mater 186: 1103-1110, 2011.

11. Ledda C, Rapisarda V, Bracci M, Proietti L, Zuccarello M, Fallico R, Fiore M and Ferrante M: Professional exposure to basaltic rock dust: Assessment by the Vibrio fischeri ecotoxicological test. J Occup Med Toxicol 8: 23, 2013.

12. Mortelmans K and Zeiger E: The Ames Salmonella/microsome mutagenicity assay. Mutat Res 455: 29-60, 2000. 
13. Radetski CM, Ferrari B, Cotelle S, Masfaraud JF and Ferard JF: Evaluation of the genotoxic, mutagenic and oxidant stress potentials of municipal solid waste incinerator bottom ash leachates. Sci Total Environ 333: 209-216, 2004.

14. Chen PW, Liu ZS, Wun MJ and Ran CL: Evaluating the mutagenicity of leachates obtained from the bottom ash of a municipal solid waste incinerator by using a Salmonella reverse mutation assay. Chemosphere 124: 70-76, 2015

15. Jordana M, Schulman J, McSharry C, Irving LB, Newhouse MT, Jordana $\mathrm{G}$ and Gauldie J: Heterogeneous proliferative characteristics of human adult lung fibroblast lines and clonally derived fibroblasts from control and fibrotic tissue. Am Rev Respir Dis 137: $579-584,1988$

16. Cardile V, Renis M, Scifo C, Lombardo L, Gulino R, Mancari B and Panico A: Behaviour of the new asbestos amphibole fluoredenite in different lung cell systems. Int J Biochem Cell Biol 36 : 849-860, 2004.

17. Mosmann T: Rapid colorimetric assay for cellular growth and survival: Application to proliferation and cytotoxicity assays. J Immunol Methods 65: 55-63, 1983.

18. Miozzi E, Rapisarda V, Marconi A, Costa C, Polito I, Spandidos DA, Libra M and Fenga C: Fluoro-edenite and carbon nanotubes: The health impact of 'asbestos-like' fibres. Exp Ther Med 11: 21-27, 2016

19. Rapisarda V, Rapisarda G, Vico GD, Gobbi L, Loreto C and Valentino M: Monitoring of fluoro-edenite fibre pollution through the study of sheep lymph nodes as a model of a biological indicator. Occup Environ Med 62: 656, 2005.

20. Martinez G, Loreto C, Rapisarda V, Masumeci G, Valentino M and Carnazza ML: Effects of exposure to fluoro-edenite fibre pollution on the respiratory system: An in vivo model. Histol Histopathol 21: 595-601, 2006.

21. Loreto C, Rapisarda V, Carnazza ML, Musumeci G, Valentino M, Fenga $\mathrm{C}$ and Martinez G: Fluoro-edenite fibres induce lung cell apoptosis: An in vivo study. Histol Histopathol 23: 319-326, 2008

22. Szychlinska MA, Parenti R, Loreto C, Salvatorelli L, Spadola S, Trovato FM, Pirri C, Rapisarda V, Pace MM, et al: Fluoro edenite-associated pathogenesis in pleural malignant mesothelioma. Acta Med Mediter 30: 981-989, 2014.

23. Musumeci G, Loreto C, Szychlinska MA, Imbesi R, Rapisarda V, Aiello FC, Castorina S and Castrogiovanni P: N-Cadherin, ADAM-10 and Aquaporin 1 expression in lung tissue exposed to fluoro-edenite fibers: An immunohistochemical study. Histol Histopathol 30: 987-999, 2015.

24. Rapisarda V, Ledda C, Ricceri V, Arena F, Musumeci A, Marconi A, Fago L, Bracci M, Santarelli L and Ferrante M: Detection of pleural plaques in workers exposed to inhalation of natural fluoro-edenite fibres. Oncol Lett 9: 2046-2052, 2015.

25. Rapisarda V, Ledda C, Migliore M, Salemi R, Musumeci A, Bracci M, Marconi A, Loreto C and Libra M: FBLN-3 as a biomarker of pleural plaques in workers occupationally exposed to carcinogenic fibers: A pilot study. Future Oncol 11 (Suppl) $35-37,2015$.

26. Ledda C, Loreto C, Pomara C, Rapisarda G, Fiore M, Ferrante M, Bracci M, Santarelli L, Fenga C and Rapisarda V: Sheep lymphnodes as a biological indicator of environmental exposure to fluoro-edenite. Environ Res 147: 97-101, 2016.

27. Musumeci G, Loreto C, Giunta S, Rapisarda V, Szychlinska MA, Imbesi R, Castorina A, Annese T, Castorina S, Castrogiovanni P, et al: Angiogenesis correlates with macrophage and mast cell infiltration in lung tissue of animals exposed to fluoro-edenite fibers. Exp Cell Res 346: 91-98, 2016.

28. Ledda C, Pomara C, Bracci M, Mangano D, Ricceri V, Musumeci A, Ferrante M, Musumeci G, Loreto C, Fenga C, et al: Natural carcinogenic fiber and pleural plaques assessment in a general population: A cross-sectional study. Environ Res 150: 23-29, 2016.
29. Rapisarda V, Salemi R, Marconi A, Loreto C, Graziano AC, Cardile V, Basile MS, Candido S, Falzone L, Spandidos DA, et al: Fluoro-edenite induces fibulin-3 overexpression in non-malignant human mesothelial cells. Oncol Lett 12: 3363-3367, 2016.

30. Ledda C, Loreto C, Matera S, Massimino N, Cannizzaro E, Musumeci A, Migliore M, Fenga C, Pomara C and Rapisarda V: Early effects of fluoro-edenite: Correlation between IL-18 serum levels and pleural and parenchymal abnormalities. Future Oncol 12: 59-62, 2016.

31. Ledda C, Loreto C, Bracci M, Mangano D, Migliore M, Ricceri V, Musumeci A, Costa C, Pomara C and Rapisarda V: High risk of pleural plaques and parenchymal abnormalities in women living in Biancavilla (Italy). Future Oncol 12: 63-65, 2016.

32. Cervini-Silva J, Antonio-Nieto-Camacho, Gomez-Vidales V, Ramirez-Apan MT, Palacios E, Montoya A, Kaufhold S, Abidin Z and Theng BK: Lipid peroxidation and cytotoxicity induced by respirable volcanic ash. J Hazard Mater 274: 237-246, 2014.

33. Fubini B and Otero Areán C: Chemical aspects of the toxicity of inhaled mineral dusts. Chem Soc Rev 28: 373-381, 1999.

34. Shukla A, Ramos-Nino M and Mossman B: Cell signaling and transcription factor activation by asbestos in lung injury and disease. Int J Biochem Cell Biol 35: 1198-1209, 2003.

35. Horwell CJ and Baxter PJ: The respiratory health hazards of volcanic ash: A review for volcanic risk mitigation. Bull Volcanol 69: 1-24, 2006

36. Damby DE, Murphy FA, Horwell CJ, Raftis J and Donaldson K: The in vitro respiratory toxicity of cristobalite-bearing volcanic ash. Environ Res 145: 74-84, 2016.

37. Sanders CL, Rhoads K and Mahaffey JA: Long-term reactivity of lung and mediastinal lymph nodes following intratracheal instillation of sandy loam soil or Mount St. Helens volcanic ash. Environ Res 32: 188-198, 1983.

38. Wehner AP, Dagle GE, Clark ML and Buschbom RL: Lung changes in rats following inhalation exposure to volcanic ash for two years. Environ Res 40: 499-517, 1986

39. Housley DG, Bérubé KA, Jones TP, Anderson S, Pooley FD and Richards RJ: Pulmonary epithelial response in the rat lung to instilled Montserrat respirable dusts and their major mineral components. Occup Environ Med 59: 466-472, 2002.

40. Vallyathan V, Robinson V, Reasor M, Stettler L and Bernstein R: Comparative in vitro cytotoxicity of volcanic ashes from Mount St. Helens, El Chichon, and Galunggung. J Toxicol Environ Health 14: 641-654, 1984

41. Wilson MR, Stone V, Cullen RT, Searl A, Maynard RL and Donaldson K: In vitro toxicology of respirable Montserrat volcanic ash. Occup Environ Med 57: 727-733, 2000.

42. Alvear-Galindo MG, Mendez-Ramirez I, Villegas-Rodriguez JA, Chapela-Mendoza R, Eslava-Campos CA and Laurell AC: Risk indicator of dust exposure and health effects in cement plant workers. J Occup Environ Med 41: 654-661, 1999.

43. AbuDhaise BA, Rabi AZ, al Zwairy MA, el Hader AF and el Qaderi S: Pulmonary manifestations in cement workers in Jordan. Int J Occup Med Environ Health 10: 417-428, 1997.

44. Ledda C and Rapisarda V: Malignant pleural mesothelioma: The need to move from research to clinical practice. Arch Med Res 47: 407, 2016

45. Rapisarda V, Loreto C, Ledda C, Musumeci G, Bracci M, Santarelli L, Renis M, Ferrante M and Cardile V: Cytotoxicity, oxidative stress and genotoxicity induced by glass fibers on human alveolar epithelial cell line A549. Toxicol In Vitro 29: 551-557, 2015.

46. Palmucci S, Torrisi SE, Caltabiano DC, Puglisi S, Lentini V, Grassedonio E, Vindigni V, Reggio E, Giuliano R, Micali G, et al: Clinical and radiological features of extra-pulmonary sarcoidosis: A pictorial essay. Insights Imaging 7: 571-587, 2016. 